\title{
Assessment of the Reliability of a Human Operator in Access Systems to Information Resources
}

\author{
Evgeniy Lavrov Sumy State \\ University Sumy, Ukraine \\ prof_lavrov@hotmail.com \\ Nadiia Pasko Sumy National Agrarian \\ University Sumy, Ukraine \\ Senabor64@ukr.net
}

\author{
Olga Lavrova Taras Shevchenko National \\ University of Kyiv Kyiv, Ukraine \\ lavrova_olia@ukr.net
}

\section{Nataliia Savina National University of Water and Environmental \\ Engineering Rivne, Ukraine n.b.savina@nuwm.edu.ua}

\begin{abstract}
The article deals with the automated systems providing information services. To describe the operator's activities, functional networks of Professor Anatoly Gubinsky were used. Models and technology for estimating the human operator reliability were obtained. Computer experiments were conducted. The possibility of taking into account the influence of the structures of activity algorithms, working conditions and operator qualifications is shown. Results will be useful to reduce the number of human operator's errors and to search for ergonomic reserves to improve the efficiency of information support systems.
\end{abstract}

Keywords: Information resources; reliability; contact-center; man-operator; ergonomics; information technology; human factor; human-machine; effectiveness; mathematical model; computer simulation

\section{INTRODUCTION}

In the conditions of the fourth industrial revolution [1] the problem of quality and efficiency of access to information resources increases [2]-[4]. A new scientific direction "Security Incident Management" begins to develop [4].

\section{PRoBlem Statement}

Undisclosed sources of efficiency can be found if there is an opportunity to conduct a thorough study of the "human factor" [5]-[10]. In this regard, the purpose of this work is based on the analysis of real contact centers that provide access to information resources:

- to analyze and describe all options of operators activity including search for causes of accidents and elimination of services quality violations;
- to substantiate the concept and method of accounting for the human factor;

- to describe the possibilities of computer simulation and analysis of options for the activities of operators.

\section{RESULTS}

A. Justification of the Need to Support Decision-Making on the Organization of the Activities of Operators

Ergonomic research of control systems and contact centers that provide access to information resources 11]-[14] revealed:

- presence of alternative algorithms of operators' activity;

- $\quad$ significant influence of operator's skills, structure of algorithms of operators' activity and working conditions on the quality of functioning.

Often, there is no decision support systems in the field of recommendation concerning the organization of the operator's activities based on the assessment of reliability and time of activity.

If we analyze all possible activity structures, their description and quality statistics, we will be able to estimate the time and the inerrancy of the implementation of incoming applications.

For this we need [14], [18]-[20]:

- mathematical models for describing and evaluating activities;

- computer technology for designing activities. 
B. Formalized Description and Assessment of Reliability for the Activities of Operators

1) Methodology of the functional network as a model of human activity.

The most effective activity modeling apparatus is a functional network by prof. Anatoly Gubinsky [16]-[18]. The modeling of elementary actions of operators and automatics is carried out using typical functional units (TFU).The most common of these are the "work operation" with the designation "rectangle", "control operation" with the designation "circle", and "alternative operation" with the designation "rectangle with several outputs". A complete description of TFU models is given in [9]. The functional network (FN) that describes the algorithmic activity of the human operator is built of those TFU. Mathematical models for accuracy and run-time estimation for typical functional structures have been obtained. Examples of models (accuracy and run-time estimation ) for (TFS) are given in Table 1. Here: $B^{\prime}$ is the probability of error-free handling operation; $K^{\prime \prime}$ is the probability of recognizing the correct operations performing; $K^{\prime \prime}$ is the probability of detecting any errors; $M(T)$ is mathematical expectation of the operational run-time; $D(T)$ is the variance of the operational run-time.

These models are used to evaluate the entire FN. The estimation is carried out by the method of folding (reduction) FN [16]-[ 18].

2) Examples of alternative embodiments of the unctional element in the customers application processing

a) A content analysis: Let's consider operator's activity organization in the sphere of public Internet services. Operator implements the application for "services restoration".

This activity can be represented as an algorithm of operation groups [7]:

- $\quad$ service application reception;

- customer's problem analysis;

- solution

- informing the client about the results of the implementation.

b) Examples of formal "problems elimination" models: The content analysis of instructional subsystem of real processes wa carries out. It revealed basic algorithms used by operators in case o

admission applications for the removal of problems in the IT services. Some of these algorithms are summarized in Table I.

Problem 1 is Limited Internet access due to the failure to notify about payment.

Problem 2 is Lack of Internet access (due to the client hardware problem).

Problem 3 is Lack of Internet access (due to the company's equipment problem).

Problem 4 is Restricted access to digital television due to the nonpayment.

Table II provides a detailed description of the troubleshooting transactions.
TABLE I. EXAMPLES OF TYPICAL FUNCTIONAL STRUCTURES

\begin{tabular}{|c|c|c|c|}
\hline $\begin{array}{l}\text { Content of } \\
\text { typical } \\
\text { functional } \\
\text { structure }\end{array}$ & $\begin{array}{c}\text { TFS } \\
\text { diagram }\end{array}$ & Index & Formula for computation \\
\hline \multirow[t]{3}{*}{$\begin{array}{l}\text { 1. Consistent } \\
\text { implementat } \\
\text { ion of } \\
\text { operations }\end{array}$} & & \begin{tabular}{|l|} 
Probability \\
of error- \\
free \\
operation \\
\end{tabular} & $B=\prod_{i=1}^{n} B_{i}$ \\
\hline & & \begin{tabular}{|l|} 
Expectation \\
value of the \\
time of \\
operation
\end{tabular} & $M(T)=\sum_{i=1}^{n} M\left(T_{i}\right)$ \\
\hline & & $\begin{array}{l}\text { Dispersion } \\
\text { of the time } \\
\text { of } \\
\text { operation }\end{array}$ & $D(T)=\sum_{i=1}^{n} D\left(T_{i}\right)$ \\
\hline \multirow{3}{*}{$\begin{array}{l}\text { 2. Cyclic } \\
\text { functional } \\
\text { structure } \\
\text { "An } \\
\text { operation } \\
\text { with action } \\
\text { control } \\
\text { without } \\
\text { restrictions } \\
\text { on the } \\
\text { number of } \\
\text { cycles" }\end{array}$} & & $\begin{array}{l}\text { Probability } \\
\text { of error- } \\
\text { free } \\
\text { operation }\end{array}$ & $B=B^{1 *} K^{11} * \frac{1}{1-\left(B^{1} * K^{10}+B^{0} * K^{10}\right)}$ \\
\hline & & \begin{tabular}{|l|} 
Expectation \\
value of the \\
time of \\
operation
\end{tabular} & $\begin{array}{l}M(T)=\left(M\left(T_{p}\right)+M\left(T_{k}\right)\right)^{*} M(L) \\
M(L)=\frac{1}{1-\left(B^{1} * K^{10}+B^{0} * K^{00}\right)}\end{array}$ \\
\hline & & $\begin{array}{l}\text { Dispersion } \\
\text { of the time } \\
\text { of } \\
\text { operation }\end{array}$ & $\begin{array}{l}D(T)=D(T)^{*}\left(M\left(T_{p}\right)+M\left(T_{k}\right)\right)^{2}+ \\
\left(D\left(T_{p}\right)+D\left(T_{k}\right)\right)^{*} M(L) \\
D(L)=\frac{B^{1 *} K^{10}+B^{0} * K^{00}}{\left(1-\left(B^{1} * K^{10}+B^{0} * K^{00}\right)\right)^{2}}\end{array}$ \\
\hline \multirow{3}{*}{$\begin{array}{l}3 . \\
\text { Functional } \\
\text { structure } \\
\text { "An } \\
\text { operation } \\
\text { with action } \\
\text { control and } \\
\text { without } \\
\text { restrictions } \\
\text { on the } \\
\text { number of } \\
\text { cycles" }\end{array}$} & & \begin{tabular}{|l|} 
Expectation \\
value of the \\
time of \\
operation \\
\end{tabular} & $\begin{array}{l}B=B_{1}^{1} * K^{11}+ \\
\left(B_{1}^{0} * K^{00}+B_{1}^{1} * K^{10}\right)^{*} B_{2}^{1}\end{array}$ \\
\hline & & $\begin{array}{l}\text { Expectation } \\
\text { value of the } \\
\text { time of } \\
\text { operation }\end{array}$ & $\begin{array}{l}M(T)=M\left(T_{p 1}\right)+M\left(T_{k}\right)+ \\
\left(B_{1}^{0} * K^{00}+B_{1}^{1} * K^{10}\right) * M\left(T_{p 2}\right)\end{array}$ \\
\hline & $P$ & $\begin{array}{l}\text { Dispersion } \\
\text { of the time } \\
\text { of } \\
\text { operation }\end{array}$ & $\begin{array}{l}D(T)=D\left(T_{p 1}\right)+D\left(T_{k}\right)+ \\
\left(B_{1}^{0} * K^{00}+B_{1}^{1} * K^{10}\right) * D\left(T_{p 2}\right)+ \\
\left(B_{1}^{0} * K^{00}+B_{1}^{1} * K^{10}\right) * \\
\left(B_{1}^{1} * K^{11}+B_{1}^{0} * K^{01}\right)^{*} M^{2}\left(T_{p 2}\right)\end{array}$ \\
\hline
\end{tabular}

c) Estimation of algorithm implementation reliability (problem 4): Here is an example of estimation procedure. Algorithm of activities is given (Table. I , column 4). Affecting factors are: qualification of operators and their working conditions.

d) Initial data formation: We have the system providing access to computer networks. Initial data is generated from the system's statistical database. These data are given in Table III.

Since working conditions (noise, vibration, lighting, tasks complexity, congestion degree, work in a queue, and etc.) substantially affect operational quality [15-17], we use correction factors method $[16,18]$. It allows calculating predicted reliability and runtime values for work severity categories greater than 1 (There are 6 categories. The higher category -worse working conditions [16]). Table HI shows reliability values for 1,3 and 6 categories only (corresponding integral scores of work severity are $18.3 ; 43.3 ; 60$ ). 
3) Software development: To solve this problem, we developed models [20] and information system [14], [19] based on the technology of functional structures typing and the folding of network functions (Table I).

4) Examples of computer modeling: Quality performance indicators for operations of the 4-th algorithm for operators of different qualification are given in Table
IV. Videogame of functional network reduction results (obtained using our software) is shown in Fig. 1. A fragment of the calculation of the results is given in Table $V$. The dependence between probability of timely and error-free execution of the algorithm and the time of decision-making of the operator is given in Fig. 2-5.

TABLE II. EXAMPLES OF FORMALIZED DESCRIPTION OF ACTIVITY ALGORITHMS (IN TERMS OF [9])

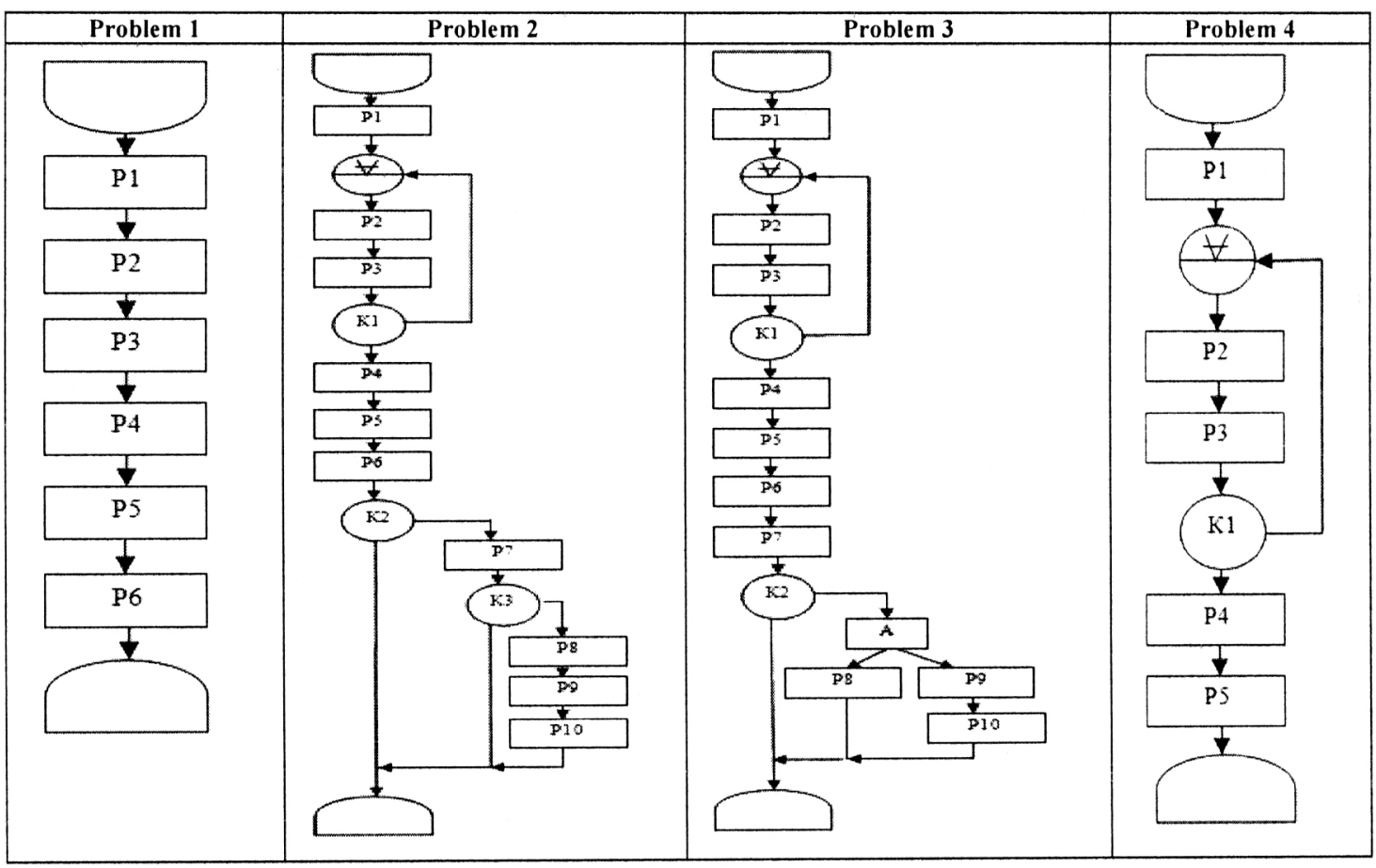

TABLE III. DESCRIPTIONS OF OPERATIONAL TROUBLESHOOTING ALGORITHMS

\begin{tabular}{|c|c|c|c|c|}
\hline & Problem 1 & Problem 2 & Problem 3 & Problem 4 \\
\hline $\mathrm{Pl}$ & $\begin{array}{l}\text { Receiving an application of } \\
\text { Internet access restriction }\end{array}$ & $\begin{array}{l}\text { Receiving an application on Internet } \\
\text { access restriction }\end{array}$ & $\begin{array}{l}\text { Receiving an application on Internet } \\
\text { access restriction }\end{array}$ & $\begin{array}{l}\text { Receiving an application } \\
\text { on Internet } \begin{array}{l}\text { access } \\
\text { restriction }\end{array}\end{array}$ \\
\hline P2 & Execution of the application & Execution of the application & Execution of the application & \begin{tabular}{|l}
$\begin{array}{l}\text { Execution of the } \\
\text { application }\end{array}$ \\
\end{tabular} \\
\hline P3 & Problem analysis & Problem analysis & Problem analysis & Problem analysis \\
\hline $\mathrm{P} 4$ & $\begin{array}{l}\text { Search for information } \\
\text { about payment }\end{array}$ & $\begin{array}{l}\text { Analysis of the client's connection } \\
\text { to the Internet }\end{array}$ & $\begin{array}{l}\text { Analysis of the client's connection to } \\
\text { the Internet }\end{array}$ & $\begin{array}{l}\text { Analysis of the client's } \\
\text { connection to the Internet }\end{array}$ \\
\hline P5 & Restoring of Internet access & $\begin{array}{l}\text { Informing client about problems } \\
\text { with user equipment }\end{array}$ & $\begin{array}{l}\text { Informing client about problems with } \\
\text { company equipment }\end{array}$ & $\begin{array}{l}\text { Informing the client about } \\
\text { the need to pay for services }\end{array}$ \\
\hline P6 & $\begin{array}{l}\text { Informing the customer } \\
\text { about problem solution }\end{array}$ & PC restarting proposal & Clarification of the problem & \\
\hline P7 & & Router restarting proposal & Problem solution & \\
\hline P8 & & $\begin{array}{l}\text { In case of no solution, informing the } \\
\text { customer of the need to call the } \\
\text { master }\end{array}$ & Additional troubleshooting operation & \\
\hline P9 & & $\begin{array}{l}\text { Making an application for a } \\
\text { challenge to master }\end{array}$ & $\begin{array}{l}\text { In case of no remote solution by the } \\
\text { operator, a challenge to master }\end{array}$ & \\
\hline $\mathrm{PlO}$ & & $\begin{array}{l}\text { Informing the customer about } \\
\text { application accepting }\end{array}$ & $\begin{array}{l}\text { Informing the customer about } \\
\text { application accepting }\end{array}$ & \\
\hline $\mathrm{Kl}$ & & $\begin{array}{l}\text { Checking the customer information } \\
\text { in the database }\end{array}$ & $\begin{array}{l}\text { Checking the customer information in } \\
\text { the database }\end{array}$ & $\begin{array}{l}\text { Checking the customer } \\
\text { information in the database }\end{array}$ \\
\hline $\mathrm{K} 2$ & & $\begin{array}{l}\text { Checking the solution of the } \\
\text { problem after router restarting }\end{array}$ & $\begin{array}{l}\text { Monitoring of the telecommunication } \\
\text { system }\end{array}$ & \\
\hline $\mathrm{K} 3$ & & $\begin{array}{l}\text { Checking the solution of the } \\
\text { problem after PC restarting }\end{array}$ & & \\
\hline
\end{tabular}


TABLE IV. QUALITY PERFORMANCE INDICATORS FOR OPERATIONS OF THE 4-TH ALGORITHM FOR OPERATORS OF DIFFERENT QUALIFICATION (DIFFERENT CATEGORIES OF SEVERITY ARE POSSIBLE)

\begin{tabular}{|c|c|c|c|c|c|c|c|c|c|c|}
\hline \multirow[t]{2}{*}{ Indicator } & \multirow[t]{2}{*}{$\begin{array}{c}\text { Designation } \\
\text { of data }\end{array}$} & \multicolumn{3}{|c|}{$\begin{array}{c}\text { Operator } 1 \text { (low } \\
\text { qualification). Category of } \\
\text { severity } \\
\end{array}$} & \multicolumn{3}{|c|}{$\begin{array}{c}\text { Operator } 2 \text { medium } \\
\text { qualification). Category of } \\
\text { severity } \\
\end{array}$} & \multicolumn{3}{|c|}{$\begin{array}{c}\text { Operator } 3 \text { (high qualification). } \\
\text { Category of severity }\end{array}$} \\
\hline & & 1 & 3 & 6 & 1 & 3 & 6 & 1 & 3 & 6 \\
\hline \multirow[b]{3}{*}{$\mathrm{Pl}$} & $\mathrm{B}$ & 0,94 & 0,89 & 0,65 & 0,95 & 0,89 & 0,65 & 0,96 & 0,9 & 0,66 \\
\hline & $\mathrm{M}, \min$ & 2,2 & 2,6 & 5,5 & 2,1 & 2,47 & 5,25 & 2 & 2,35 & 5 \\
\hline & $\mathrm{D}, \mathrm{min}^{2}$ & 0,49 & 0,52 & 0,64 & 0,47 & 0,52 & 0,61 & 0,45 & 0,5 & 0,58 \\
\hline \multirow[b]{3}{*}{ P2 } & $\mathrm{B}$ & 0,97 & 0,91 & 0,67 & 0,98 & 0,92 & 0,67 & 0,99 & 0,93 & 0,68 \\
\hline & $\mathrm{M}, \min$ & 3,3 & 3,89 & 8,25 & 3,15 & 3,71 & 7,87 & 3 & 3,5 & 7,5 \\
\hline & $\mathrm{D}, \mathrm{min}^{2}$ & 0,11 & 0,12 & 0,14 & 0,1 & 0,11 & 0,13 & 0,1 & 0,11 & 0,13 \\
\hline \multirow[b]{3}{*}{ P3 } & $\mathrm{B}$ & 0,95 & 0,89 & 0,66 & 0,96 & 0,9 & 0,66 & 0,97 & 0,91 & 0,67 \\
\hline & $\mathrm{M}, \mathrm{min}$ & 5,5 & 6,5 & 13,75 & 5,25 & 6,18 & 13,1 & 5 & 5,9 & 12,5 \\
\hline & $\mathrm{D}, \mathrm{min}^{2}$ & 0,55 & 0,62 & 0,72 & 0,52 & 0,59 & 0,68 & 0,5 & 0,56 & 0,65 \\
\hline \multirow[b]{3}{*}{$\mathrm{P} 4$} & $\mathrm{~B}$ & 0,967 & 0,91 & 0,67 & 0,977 & 0,92 & 0,67 & 0,987 & 0,93 & 0,68 \\
\hline & $\mathrm{M}, \min$ & 2,75 & 3,2 & 6,87 & 2,63 & 3,1 & 6,6 & 2,5 & 2,95 & 6,25 \\
\hline & $\mathrm{D}, \min ^{2}$ & 0,33 & 0,35 & 0,4 & 0,3 & 0,34 & 0,39 & 0,3 & 0,34 & 0,39 \\
\hline \multirow[b]{3}{*}{ P5 } & $\mathrm{B}$ & 0,96 & 0,9 & 0,67 & 0,97 & 0,91 & 0,67 & 0,98 & 0,92 & 0,67 \\
\hline & $\mathrm{M}, \mathrm{min}$ & 2,2 & 2,6 & 5,5 & 2,1 & 2,5 & 5,25 & 2 & 2,35 & 5 \\
\hline & $\mathrm{D}, \min ^{2}$ & 0,44 & 0,48 & 0,57 & 0,42 & 0,49 & 0,55 & 0,4 & 0,43 & 0,52 \\
\hline \multirow[b]{4}{*}{$\mathrm{K} 1$} & $\mathrm{~K}^{11}$ & 0,975 & 0,95 & 0,9 & 0,985 & 0,96 & 0,91 & 0,995 & 0,992 & 0,99 \\
\hline & $\mathrm{K}^{00}$ & 0,978 & 0,961 & 0,95 & 0,988 & 0,975 & 0,96 & 0,998 & 0,99 & 0,975 \\
\hline & $\mathrm{M}, \min$ & 3,3 & 3,45 & 3,7 & 3,15 & 3,25 & 3,5 & 3 & 3,2 & 4 \\
\hline & $\mathrm{D}, \min ^{2}$ & 0,22 & 0,4 & 0,68 & 0,21 & 0,3 & 0,67 & 0,2 & 0,4 & 0,7 \\
\hline
\end{tabular}

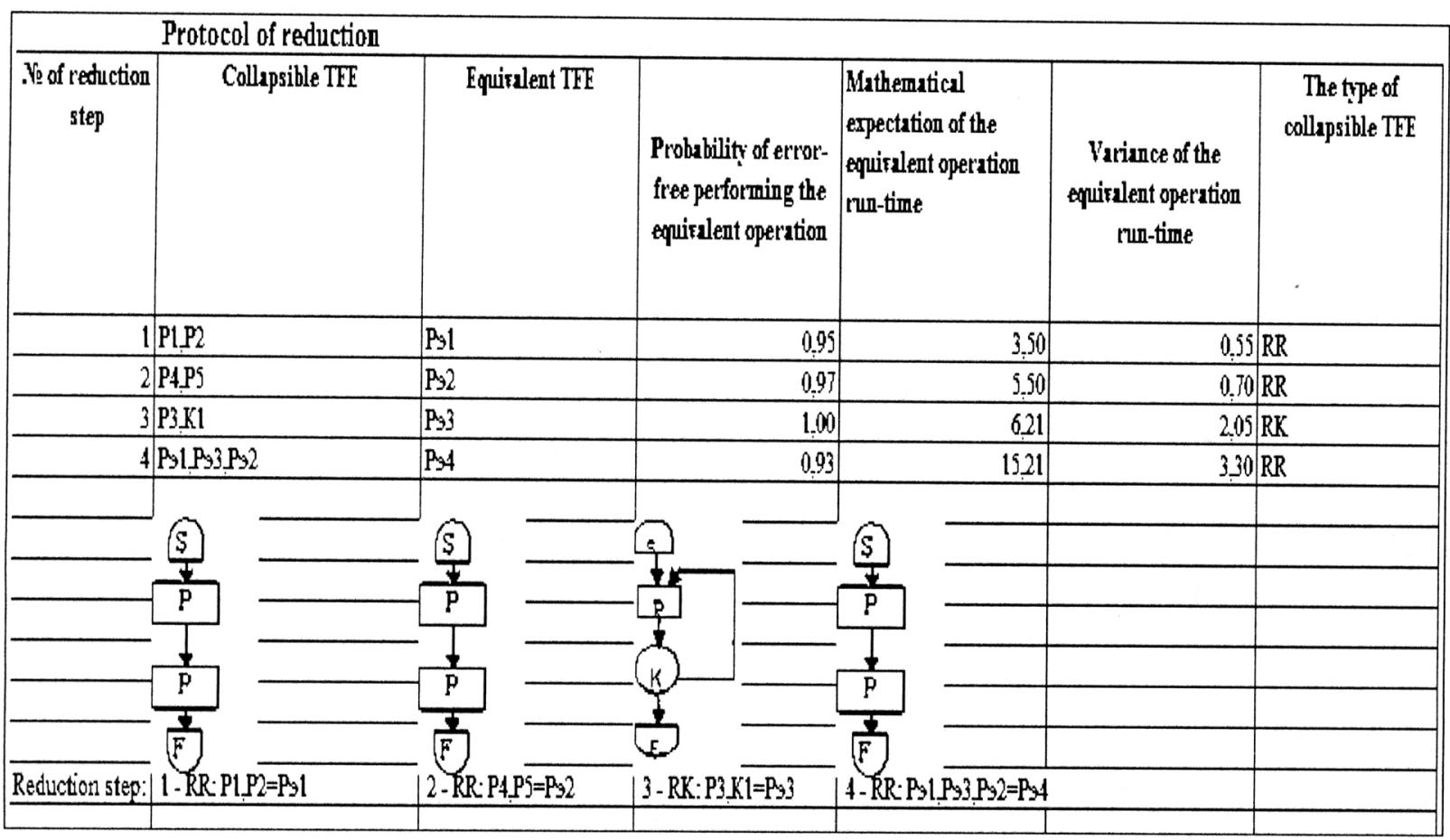

Fig. 1. An example of functional network reduction protocol for type 4 algorithm (highly skilled operator, severity category -1 ) 
TABLE V. RESULTS OF THE EVALUATION OF TECHNICAL SUPPORT OPERATORS

\begin{tabular}{|c|c|c|c|c|c|c|c|c|c|c|}
\hline \multirow[t]{2}{*}{ Indicator } & \multirow{2}{*}{$\begin{array}{c}\text { Decision- } \\
\text { making time, } \\
\text { min }\end{array}$} & \multicolumn{3}{|c|}{$\begin{array}{c}\text { Operator 1. Category of } \\
\text { severity }\end{array}$} & \multicolumn{3}{|c|}{$\begin{array}{c}\text { Operator 2. Category of } \\
\text { severity }\end{array}$} & \multicolumn{3}{|c|}{$\begin{array}{c}\text { Operator 3. Category of } \\
\text { severity }\end{array}$} \\
\hline & & 1 & 3 & 6 & 1 & 3 & 6 & 1 & 3 & 6 \\
\hline $\begin{array}{l}\text { Probability of error- } \\
\text { free performing the } \\
\text { algorithm B }\end{array}$ & & 0,872 & 0,72 & 0,25 & 0,9 & 0,74 & 0,26 & 0,93 & 0,79 & 0,35 \\
\hline $\begin{array}{l}\text { Mathematical } \\
\text { expectation of the } \\
\text { algorithm performing } \\
\text { time } M(t) \text {, min }\end{array}$ & & 20,57 & 26,2 & 58,2 & 19,3 & 24,5 & 50,7 & 15,2 & 20,6 & 45,1 \\
\hline $\begin{array}{ll}\text { Variance } & \text { of the } \\
\text { algorithm } & \text { run-time } \\
D(t), m i n & \end{array}$ & & 10,09 & 15,1 & 30,1 & 8,95 & 14 & 29,4 & 3,3 & 11,7 & 20,5 \\
\hline \multirow{6}{*}{$\begin{array}{lr}\text { Probability } & \text { of } \\
\text { performing } & \text { the } \\
\text { algorithm in time } \\
\text { Ptim(To) }\end{array}$} & 15 & 0,29 & 0,13 & 0,08 & 0,32 & 0,25 & 0,11 & 0,48 & 0,32 & 0,07 \\
\hline & 21 & 0,52 & 0,30 & 0,11 & 0,58 & 0,40 & 0,16 & 0,96 & 0,51 & 0.12 \\
\hline & 25 & 0,67 & 0,45 & 0,14 & 0,74 & 0,51 & 0,19 & 1,00 & 0,65 & 0,16 \\
\hline & 29 & 0,80 & 0,61 & 0,17 & 0,86 & 0,63 & 0,23 & 1,00 & 0,76 & 0,22 \\
\hline & 32 & 0,87 & 0,72 & 0,19 & 0,92 & 0,70 & 0,26 & 1,00 & 0,84 & 0,26 \\
\hline & 40 & 0,97 & 0,91 & 0,27 & 0,99 & 0,87 & 0,36 & 1,00 & 0,95 & 0,40 \\
\hline \multirow{6}{*}{$\begin{array}{l}\text { Probability of error- } \\
\text { free and timely } \\
\text { performing r the } \\
\text { algorithm B B*Ptim } \\
\text { (To) }\end{array}$} & 15 & 0,25 & 0,16 & 0,02 & 0,28 & 0,18 & 0,03 & 0,44 & 0,25 & 0,03 \\
\hline & 21 & 0,45 & 0,26 & 0,03 & 0,52 & 0,30 & 0,04 & 0,89 & 0,41 & 0,05 \\
\hline & 25 & 0,58 & 0,34 & 0,03 & 0,66 & 0,38 & 0,05 & 0,93 & 0,51 & 0,07 \\
\hline & 29 & 0,70 & 0,41 & 0,04 & 0,77 & 0,46 & 0,06 & 0,95 & 0,60 & 0,09 \\
\hline & 32 & 0,76 & 0,47 & 0,05 & 0,83 & 0,52 & 0,07 & 0,96 & 0,66 & 0,10 \\
\hline & 40 & 0,85 & 0,59 & 0,07 & 0,89 & 0,64 & 0,09 & 0,99 & 0,75 & 0,15 \\
\hline
\end{tabular}

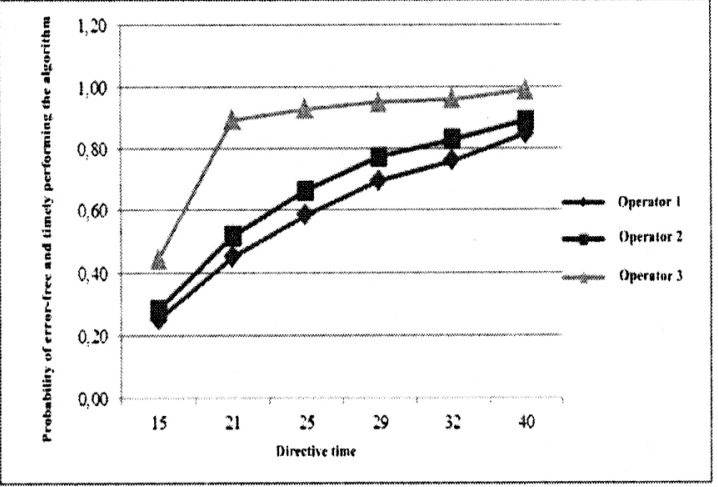

Fig. 2. The dependence between the probability of timely and error-free performing the algorithm (problem 4 solution) and the decisionmaking time (for normal working conditions)

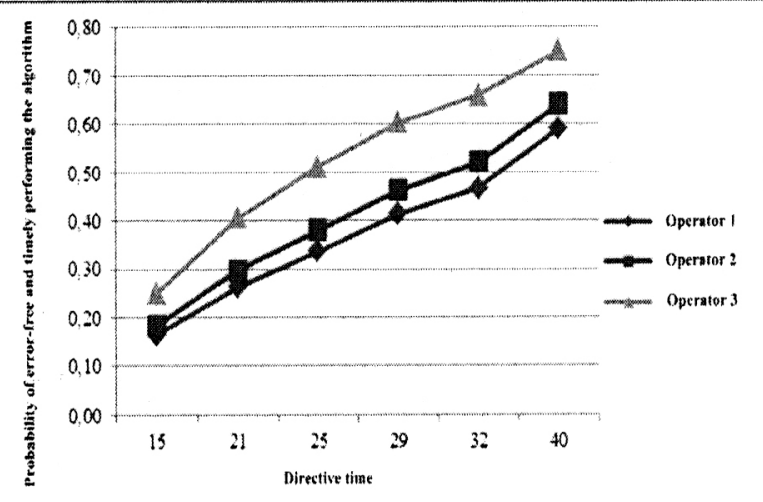

Fig. 3. The dependence between the probability of timely and error-free performing the algorithm (problem 4 solution) and the decisionmaking time (for the third category of work severity)

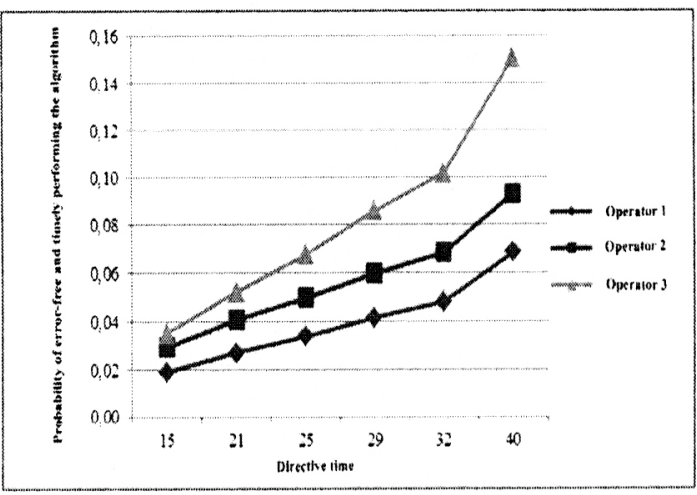

Fig. 4. The dependence between the probability of timely and error-free performing the algorithm (problem 4 solution) and the decisionmaking time (for the sixth category of work severity)

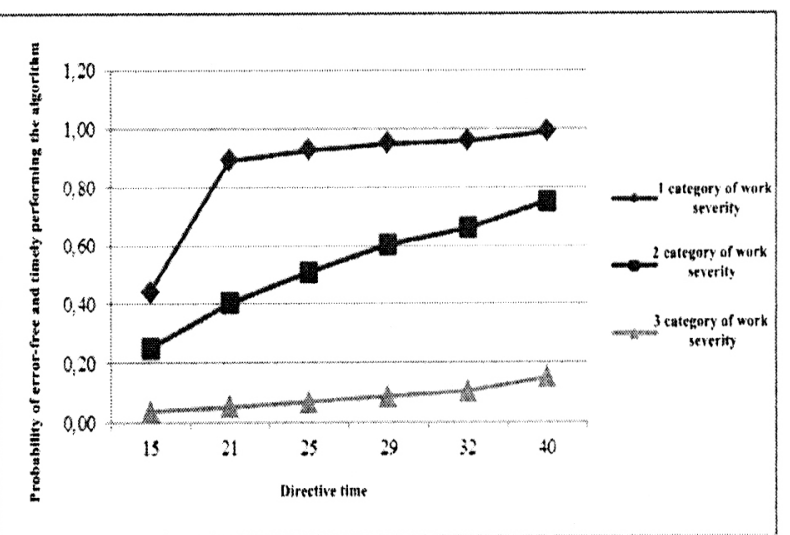

Fig. 5. The dependence between the probability of timely and error-free performing the algorithm (problem 4 solution) and the decisionmaking time for different work conditions (for the 3 operators of high qualification) 
Examples of calculations are prepared on the basis of analysis of the work of specific provider centers located in Sumy (Ukraine) with the participation of the student of postgraduate education Krivodub Anna and the student Shapochka Julia (Sumy State University).

\section{CONCLUSION}

The work is done within the man-system approach to modeling automated systems, solving one of the practical problems of ergonomic support, which was formulated in [7]. Thus, we have laid the foundations of decision support for the organization of the activities of operators in automated systems.

Scientific novelty. Unlike the existing intuitive methods, we developed:

- formal methods to describe and valuate the reliability and timing of the functions (in relation to systems of information resources);

- new method of automatic reduction of a functional network;

- new method of taking into account the individual characteristics of the human-operator and working conditions at the workplace.

A new information technology was proposed, which should be useful for the practice of the work of contact centers. Results can also be extended to other types of automated systems. This will allow in the future to reduce the number of errors and accidents caused by the human operator.

\section{REFERENCES}

[1] R. Y, Zhong, X Xu, E. Klotz, et al., "Intelligent manufacturing in the context of industry 4.0: a review," Engineering, vol. 3, no. 5, pp. 616-630,2017. [2] A. Vaxevanou and N. Konstantopoulos, "Basic

Principles the

Philosophy of Outsourcing," Procedia-Social and Behavioral Sciences, vol. 175, pp. 567-571, 2015

[3] J. Rhodes, P. Lok, W. Loh and V. Cheng, "Critical success factors in relationship management for services outsourcing," Service Business, vol, 10, pp. 59-86, 2016

[4] A. Belov and E. Ulaeva, "Mathematical model of incident management in the composite applications," in International Conference "Quality Management.Transport and Information Security, Information Technologies" (IT\&QM\&IS), St. Petersburg, 2017, pp. ' 477-480. DOI: https://doi.Org/IO.l 109/ITMQIS.2017.8085866

[5] A. N. Zhirabok, N. A. Kalinina and A. E. Shumskii, "Technique of monitoring a human operator's behavior in man-machine systems," Journal of Computer and Systems Sciences International, vol. 57, no. 3, pp. 443-452,2018.

[6] V. A. Sedov, N. A. Sedova and S. V. Glushkov, "The fuzzy model of ships collision risk rating in a heavy traffic zone," Vibroengtneering PROCED1A, vol. 8, pp. 453-458, 2016.

[7] M P. Xu, .1. Wang, M. Yang, W. Wang, Y. Bai, Y., and Y. Song, "Analysis of operator support method based on intelligent dynamic interlock in leadcooled fast reactor simulator," Annals of Nuclear Energy, vol. 99, pp. 279282, 2017.

[8] P. C. Cacciabue, "Human error risk management for engineering systems: methodology for design, safety assessment, accident investigation and training," Reliability Engineering \& System
Safety, vol. 83, issue 2, pp. 229-269, 2014. DOI: https://doi.Org/10.1016/i.ress.2003.09.013

[9] J. Dul, R. Bruder, P. Buckle, P. Carayon, P. Falzon and W. S. Marraset, "A Strategy for human factors/ergonomics: developing the discipline and profession," Ergonomics, vol. 55(4), pp. 377-395,2012. DOI: https://doi.org/10.1080/00140139.2012.661087

[10] M. Havlikovaa, M. Jirglb and Z. Bradac, "Human Reliability in Man-Machine Systems," Procedia Engineering, vol. 100, pp. 1207-1214, 2015. DOI:

https://doi.org/10.1016/j proeng.2015.01.485

11] E. Lavrov, N. Pasko, A. Tolbatov and V, Tolbatov, "Ergonomic Reserves for Improving Reliability of Data Processing in Distributed Banking Systems," in Proceedings of 2nd International Conference on Advanced Information and Communication Technologies-2017 (AlCT-20ח), Lviv, Ukraine, July 47, 2017, pp. 79-82.

[12] F. De Felice and A. Petrillo, "Methodological Approach for Performing Human Reliability and Error Analysis in Railway Transportation System," International Journal of Engineering and Technology, vol. 3(5), pp. 341353, 2011.

[13] E. Lavrov, N. Pasko, A. Krivodub, N. Barchenko and V. Kontsevich, "Ergonomics of IT outsourcing. Development of a mathematical model to distribute functions among operators," Eastern European Journal of Enterprise Technologies, vol.4 (80), pp. 32^10, 2016. DOI: https://doi.org/10.15587/1729-4061.2016.66021.

[14] E. Lavrov, N. Pasko, "Automation of assessing the reliability of operator's activities in contact centers that provide access to information resources," in Proceedings of the I4 ${ }^{1,}$ International Conference on ICT in Education Research and Industrial Applications. Integration, Harmonization and Knowledge Transfer, Kyiv, Ukraine, May 14-17, 2018, vol. I: Main Conference, pp. 445-448.

[15] P. C. Li, L. Zhang, L. C. Dai and X. F. Li, "Study on operator's SA reliability in digital NPPs. Part I: The analysis method of operator's errors of situation awareness," Annals of Nuclear Energy, vol. 102, pp. 168-178,2017.

[16] A. N. Adamenko, A. T. Asherov, I. L. Berdnikov et al, Informacionnoupravljajushhie cheloveko-mashinnye sistemy: Issledovanie, proektirovanie, ispytanija. Spravochnik [Information controlling human-machine systems. research, design, testing. Reference book], A.I. Gubinsky \& V.G. Evgrafov, eds. Moscow, Russia: Mashinostroenie, 1993. (In Russian).

[17] M. G. Grif, O. Sundui and E. B. Tsoy, "Methods of desingning and modeling of man-machine systems," in Proc. of International Summer workshop Computer Science 2014, 2014, pp. 38-40.

[18] P. P. Chabanenko. Issledovanie bezopasnosli i effektivnosti funktsionirovaniya sistem achelovek - tehnika» ergonomichnyimt setyami [Research of the safety and efficiency of the functioning of systems "human - technics" by ergonomic networks], Sevastopol, Ukraine: Academy of naval forces named after P. S. Nahimov, 2012. (In Russian)

[19] E, Lavrov, A. Volosiuk, N. Pasko, V. Gonchar and G.Kozhevnikov, "Computer Simulation of Discrete Human-Machine Interaction for Providing Reliability and Cyber-security of Critical Systems," in Proceedings of the Third International Conference Ergo-2018: Human Factors in Complex Technical Systems and Environments (Ergo-2018), St. Petersburg, Russia, July 4-7, 2018, pp. 67-70. DOI: https://doi.org/10.1109/ERGO.2018.8443846

[20] E. Lavrov, N. Pasko, "Development of Models for Computer Systems of Processing Information and Control for Tasks of Ergonomic Improvements," in International Conference on Information and Software Technologies, ICIST 2018, Vilnius, Lithuania, October 4-6, 2018, pp. 98-109. DOI: https://doi.org/10.1007/978-3-319-99972-2_8 